\title{
WHICH VARIABLES COULD ENHANCE INDONESIAN CONSUMERS' INTENTION IN ADOPTING E-PAYMENT AS CONSUMERS' MAIN PAYMENT METHOD?
}

\author{
Nicholas Wilson \\ Department of Management, Universitas Bunda Mulia \\ wp8989@yahoo.com
}

Masuk : 02-04-2021, revisi : 12-04-2021, diterima untuk diterbitkan : 12-04-2021

\begin{abstract}
This study was commenced to fully understand the impact that was given by both Security Risk and Perceived Usefulness in strengthening or enhancing Consumers' Intention to adopt or use E-Payment services as their main payment method every time consumers are conducting any buying or transactional activities toward any stores (either online stores or offline store) which they've visited. Implementing survey method, questionnaires were chosen and implemented as the main tools to collect and gather all of the required data from the respondents. A total of 200 respondents participated in this study, which, all of the respondents who participated in this study are those who've chosen and used E-Payment as their main payment method when they're conducting any transactional buying activities on any stores at least 5 times for the past 1 year. All of these data then were further analyzed, in which author would like to conclude that all of these data were valid, reliable, and usable to be further processed in this study. Using PLS-SEM as the main method in analyzing and processing all of the data gathered in this study, the author would like to conclude that both Security Risk and Perceived Usefulness have a significant impact on Indonesian Consumers' Intention to adopt E-Payment services as their main payment method for any transactional activities conducted by the consumers.
\end{abstract}

Keywords: Security Risk, Perceived Usefulness, Intention to Adopt, Indonesian E-Payment Sector

Abstrak: Studi ini dilakukan guna mengetahui bagaimana pengaruh yang diberikan oleh Security Risk dan Perceived Usefulness terhadap Intensi Konsumen Indonesia di dalam mengadopsi serta menggunakan E-Payment sebagai metode pembayaran yang dipilih setiap kali konsumen melakukan transaksi pembelian produk ataupun jasa pada suatu toko tertentu. Adapun dengan menggunakan ataupun mengimplementasikan metode survei, penelitian ini menggunakan Kuesioner sebagai alat yang akan digunakan untuk mengumpulkan seluruh data yang diperlukan dari seluruh responden yang berpartisipasi pada studi ini. Sebanyak 200 responden berpartisipasi pada studi ini, yang dimana, seluruh responden merupakan Konsumen Indonesia yang pernah menggunakan E-Payment sebagai metode utama mereka di dalam melakukan berbagai aktivitas pembayaran atas transaksi yang dilakukan paling sedikit 5 kali dalam kurun waktu 1 tahun terakhir. Adapun setelah melakukan pengecekan secara menyeluruh terhadap seluruh data yang terkumpul, peneliti dapat menyimpulkan bahwa seluruh data yang terkumpul pada penelitian ini merupakan data yang valid, reliable serta dapat diproses secara lebih lanjut pada studi ini. Dengan menggunakan PLS-SEM sebagai metode pengolahan data yang dipilih pada studi ini, peneliti dapat menyimpulkan bahwa kedua variabel, yaitu Security Risk serta Perceived Usefulness berpengaruh signifikan terhadap Intensi Konsumen Indonesia di dalam mengadopsi serta menggunakan sistem E-Payment sebagai metode pembayaran utama yang dipilih ketika konsumen melakukan transaksi pembelian.

Kata Kunci: Security Risk, Perceived Usefulness, Intention to Adopt, Sektor E-Payment di Indonesia 


\section{INTRODUCTION}

\section{Research Background}

E-Payment or Electronic Payment had become one of a few sectors which experiences rapid growth in Indonesia, in which, in recent years, the number of people or consumers who are adopting and using E-Payment services as their main payment method in Indonesia had been rapidly escalating or increasing from time to time. According to the latest statistical data provided and published by Statista (Nurhayati-Wolff, 2021), as of 2020, around 90\% of Indonesians have stated that they've adopted or chosen E-Payment as their main payment method when they're making any transactional or purchasing activities regarding the goods or services which they want to purchase had been increasing, in which, such number showed that, as the time goes by, more and more people in Indonesia are adopting or using E-Payment services as their main payment method as compared to Cash as consumers' preferred paying method or tools.

In regard with this case, as of why more and more people are starting or opting to use and adopt E-Payment services as their main payment method as compared to the more traditional way, Practicality and Simplicity have been often suspected as two main factors which could explain why the number of people who are using E-Payment keeps increasing on an annual basis. This is mainly because by adopting or using E-Payment services as the consumers' main payment method, it eliminates the necessity of carrying a significant amount of cash while consumers would like to conduct any transactional activities, thus reducing Consumers' effort to withdraw cash from the nearby ATMs, while at the same time, adopting E-Payment services as the consumers' main payment method could also reduce the risks or probability that consumers' cash could get stolen by irresponsible parties when consumers are carrying the money with them. In this case, using E-Payment could reduce such threats of risks since consumers just need to deposit some specified amount of money on their E-Payment applications (which they've downloaded on their smartphones or tablets), and that once consumers would like to make any payment or purchasing activities toward certain stores, they could just open their E-Payment application, input (or confirm) a specified amount of money that they had to pay, and after confirming and ensuring that the amount of money that consumers had to pay was right, then consumers could just completing and confirming their payment through their apps through one click, and that the amount of balance that consumers once deposited on their E-Payment application will be debited in accordance with how much price that consumers should pay for the goods or services that they've bought. Based on the illustration above, it was clear and understandable that conducting any transactional, purchasing, or payment activities using E-Payment services was far more practical and simpler as compared to if we're still using Cash or Physical Money as our Purchasing Method when we would like to buy something, and that such scenario or argument could explain the increasing trend of E-Payment adoption and usage rate in Indonesia. Furthermore, other than analyzing such trend based on the increasing number of people who are using or adopting the so-called E-Payment, the rapid development of the E-Payment service in Indonesia could also be assessed or seen based on the increasing number of companies doing or conducting their business within the Indonesian E-Payment sector. The emergences of companies or E-Payment applications, such as OVO, GOPAY, LinkAja, DANA, Shopee Pay, and the other E-Payment applications or companies had also contributed to the increasing number of Indonesians who are using or adopting E-Payment, which eventually make a great contribution to the increasing popularity and the growth of E-Payment sector in Indonesia.

Meanwhile, still related with the increasing usage or adoption rate of E-Payment services by the Indonesian Consumers, several authors had stated or determined that both Security Risk and Perceived Usefulness are two factors or variables which greatly affected consumers or people's intention to adopt or use E-Payment service as their main payment method while making any transactional activities on their own. Security Risk itself could be understood as 
people's personal or own perception regarding any kind of risks that people of consumers should face, in which these risks were related with the possibilities that all of the personal data which were provided by the consumers to the company could be stolen or misused by the other parties. In this case, still related with the basic concept of E-Payment, since people or consumers are required to provide or input several personal (and important) data on the EPayment apps which had been downloaded, there's a high chance or high risk that such data might get leaked or misused for negative or bad purposes which might harm consumers or people who are using the application. Therefore, it was incredibly important for every company which provided or created such an E-Payment platform to fully ensure that the entire systems which were implemented or installed on the platform were secured enough to block or prevent any kinds of data or security breach from happening on the E-Payment platform, in which, when companies were able to ensure that the platform or E-Payment application which had been developed was highly secured, then it could boost consumers' confidence toward the system, in which, such confidence could eventually increase consumers' intention to adopt or use the E-Payment system.

Furthermore, other than Security Risk, Perceived Usefulness had also been revealed by several authors to be the other variable that could significantly affect people's willingness or intention to adopt E-Payment services (or the other forms of technology) as their main method in completing their payment activities. Could be understood as consumers or people's personal feelings or judgment regarding whether or not the new technology (which adopted by the customers) could positively improve the state and the quality of consumers' work, people or consumers' perception regarding whether or not using or adopting E-Payment services as their main payment method could bring some positive aspects toward their life (and toward their buying behavior) might significantly and greatly affect consumers' behavior or decision regarding whether or not they'll adapt or use E-Payment services as their preferred payment method as opposed to the more conventional and traditional one (which is by using Cash to complete every payment activities that should be completed by the consumers). Therefore, it should be understood that every company which is developing the E-Payment apps and systems should ensure that each and every piece of system or features which were developed and installed on the apps were sophisticated enough to ensure that consumers will gain some additional benefits or values when they're using the E-Payment system or apps, in which, such benefits could make consumers think that adopting E-Payment will bring additional benefits which will improve their buying experiences, thus increasing consumers' intention to finally adopt and use the E-Payment system. Based on all of these explanations and arguments, the author was interested to determine whether security risk and perceived usefulness could have a significant impact on consumers' intention to adopt E-Payment systems or apps as consumers' main payment method in Indonesia.

\section{Purpose of the Study}

The main purpose of this study was to fully and thoroughly understand whether or not people or consumers' perception regarding the security risks which might occur when they're using or adopting the E-Payment system or application (Security Risk), together with people or consumers' perception or judgment regarding whether or not using E-Payment services as their main payment method brings some additional values of advantages toward their life or the work that they're currently doing (Perceived Usefulness) could significantly affect people or consumers' intention in Indonesia to adopt and use E-Payment services as their main and preferred payment method.

\section{LITERATURE REVIEW \\ Security Risk}

Security Risk could be defined as consumers' or people's judgment or perception regarding any kinds of possibilities that all personal judgment given by the customers to the 
company could be stolen in certain ways (Stocchi et al., 2019). Furthermore, Security Risk could also be understood as consumers' feelings or perceptions regarding whether or not the company could keep and ensure the safety of all personal and important data which the consumers store on the system developed by the company (Trinh et al., 2020).

\section{Perceived Usefulness}

Perceived Usefulness could be defined as consumers' or individuals' judgment regarding whether or not the implementation or adoption of certain technologies will improve and change the way consumers or people are doing their job (Wilson, 2019). Furthermore, Perceived Usefulness could also be defined as consumers' personal feelings regarding whether or not the new technology (which adopted by the customers) could positively improve the state and the quality of consumers' work (Shiau et al., 2020).

\section{Intention to Adopt}

Similar to the basic concept of Purchase Intention, Intention to Adopt could be defined as consumers' willingness to learn and use certain technologies and integrate them with how the consumers are doing their job (Ariffin et al., 2018). Moreover, Intention to Adopt could also be understood as consumers' personal decision and desire to adopt new technologies developed by a certain company that hasn't been used or adopted before by the consumers (Trinh et al., 2020).

\section{The Effect of Security Risk and Perceived Usefulness toward Intention to Adopt}

Previous studies by Ariffin et al. (2018) and Trinh et al. (2020) had found out the significant and negative impact which was given by Security Risk on Consumers' Intention to Purchase or Adopt certain technology, in which, when consumers thought that there will be low (or even no) possibilities of consumers experiencing or suffering from any kinds of security breaches related with all of the data and personal information that consumers gave to the company, then such beliefs or perception could increase consumers' believe in the system, which eventually could increase or strengthen consumers' intention to use or adapt the system or technologies developed by the company. Furthermore, another study conducted by Stocchi et al. (2019), Shaiu et al. (2020), and Trinh et al. (2020) had also found out the significant and positive impact of perceived usefulness on consumers' intention to adopt or use certain systems or technologies. Based on these studies, the author would like to propose the following hypotheses:

\section{H1: Security Risk had a significant effect on Consumer's Intention to Adopt} H2: Perceived Usefulness had a significant effect on Consumer's Intention to Adopt Figure 1

\section{Research Model}

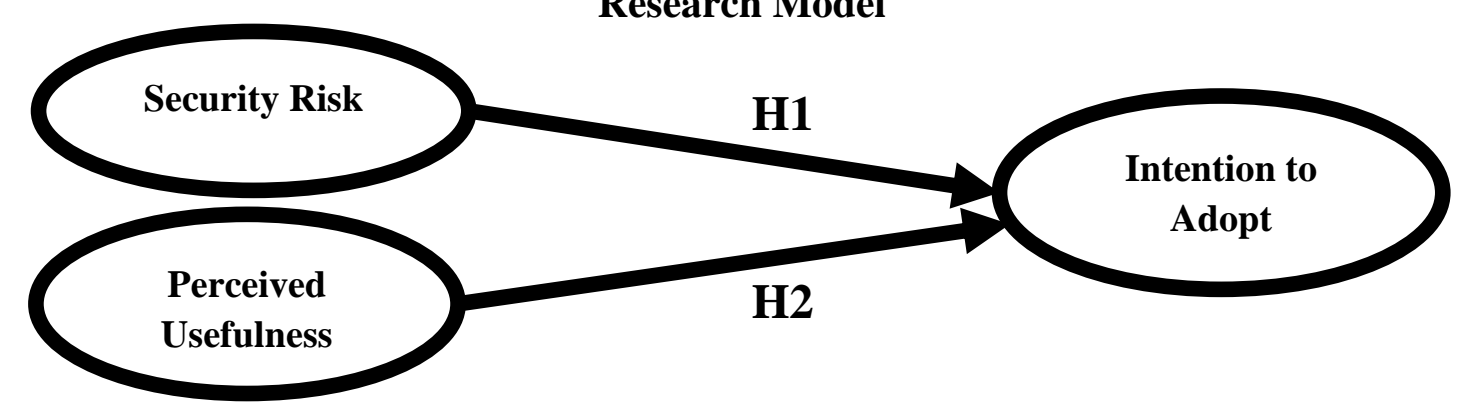

\section{RESEARCH METHODOLOGY}

This study implements a survey method, in which, questionnaires were selected as the main tools which will be implemented to collect all of the data from all of the respondents. A total of 200 respondents participated in this study, in which all of the respondents who participated in this study were those who've selected and used any E-Payment System or Apps as their main payment method for any kinds of transactions conducted by the consumers at least 5 times for the past 1 year. Furthermore, regarding the scale used in this study, the 5- 
points Likert scales were chosen, in which respondents could give their true and sincere response regarding each and every statement presented on the questionnaire, in consumers' responses were ranging from "1" (which express respondents' strong disagreement toward the respective statement), to "5" (which express respondents' strong agreement toward the respective statement).

Furthermore, regarding the indicators implemented and used in this study, a total of 3 indicators representing Security Risk, 3 indicators representing Perceived Usefulness, and 4 indicators representing Intention to Adopt were adapted from Ariffin et al. (2018), Stocchi et al. (2019), Wilson (2019), and Trinh et al. (2020), in which brand satisfaction and brand attitude were each represented by 3 indicators, while brand loyalty was represented by 4 indicators. After collecting all of the data from the respondents, these data were further assessed using the PLS-SEM method (with the help of SmartPLS 3.3.2 software) to find out the relationships between variables discussed in this study. As for the brief or general analysis regarding the profile of the respondents, most of the respondents were female (74.5\%), and that most of them had used E-Payment services more than 10 times for any transactional or payment activities which they conducted for the past 1 year.

\section{RESULTS AND CONCLUSIONS}

\section{Outer Model Assessment, Inner Model Assessment, and Hypotheses Testing Results}

Outer Model Assessment, Inner Model Assessment, and Hypotheses Testing Results

Before conducting a thorough Inner Model analysis regarding the impact of both security risk and perceived usefulness on consumers' intention to adopt, and before determining whether or not all of the hypotheses proposed in this study were supported, using the PLS-SEM method, the Outer Model was first conducted to ensure the validity and the reliability of each and every single indicator and variable assessed or discussed in this study. In this case, after conducting the Outer Model Assessment on both the indicators and the variables discussed in this study, the author determined that all data were declared Valid and Reliable in this study, since all indicators and variables had successfully satisfied the following criteria, such as the factor loadings and the composite reliability value of each variable should be above 0.7 , and AVE value of each variable should be above 0.5 and that the square root of AVE of each variable should be greater than the correlation value with the other variables (discriminant validity)

After concluding and determining that all of these criteria had been satisfied, the author then decided to conduct the Inner Model Analysis to determine the relationships of each variable, together with determining whether to support or reject the hypotheses proposed in this study. In this case, based on the results of the path coefficient analysis commenced in this inner model assessment, the author would like to conclude that all hypotheses proposed in this study were supported since the P-Value (Sig. Value) of all hypotheses were well below the minimum acceptable value of 0.05 (P-Value $<0.05)$.

\section{Table 1}

\section{Path Coefficient Analysis \& Hypotheses Testing}

\begin{tabular}{|l|c|c|}
\hline \multicolumn{1}{|c|}{ Hypotheses } & Sig.Value & Conclusions \\
\hline $\begin{array}{l}\text { H1: Security Risk had a significant effect on Consumer's Intention to } \\
\text { Adopt }\end{array}$ & $\mathbf{0 . 0 0 0}$ & H1 Supported \\
\hline $\begin{array}{l}\text { H2: Perceived Usefulness had a significant effect on Consumer's } \\
\text { Intention to Adopt }\end{array}$ & $\mathbf{0 . 0 0 0}$ & H2 Supported \\
\hline
\end{tabular}

Source: Data Analysis (2021)

\section{Conclusion}

Based on the results of the path coefficient analysis and the hypotheses testing assessment presented in Table 1, it could be concluded that both Security Risk and Perceived Usefulness had a significant impact toward enhancing or strengthening consumers' intention to adopt or use E-Payment services as their main payment method for any kinds of transaction or buying activities conducted by the consumers in Indonesia. Regarding these results, the authors would 
like to suggest to all companies which developed an E-Payment system or apps in Indonesia to ensure that all security protection which was developed and installed on the systems or apps were strong and secure enough to prevent the possibility that these data could get stolen by irresponsible parties, in which such scenario could badly hurt the company's reputation, and could weaken consumers' intention to use or adapt the system. Furthermore, companies should also ensure that all features installed on the E-Payment apps (and presented to the consumers) were valuable features that could be accepted and perceived positively by the consumers, which, when consumers think that the new technology or features developed by the companies could bring additional values or benefits which could improve the quality of their life and buying behavior, then there's a high chance that consumers will eventually decide to adopt and use the E-Payment system as their main payment method.

\section{REFERENCES}

Ariffin, S. K., Mohan, T., \& Goh, Y. N. (2018). Influence of consumers' perceived risk on consumers' online purchase intention. Journal of Research in Interactive Marketing, 12(3), 309-327. https://doi.org/10.1108/JRIM-11-2017-0100

Nurhayati-Wolff, H. (2021). Share of e-payment users among respondents in Indonesia in 2020. Statista.Com. https://www.statista.com/statistics/1105688/indonesia-share-of-epayment-users/

Shiau, W. L., Yuan, Y., Pu, X., Ray, S., \& Chen, C. C. (2020). Understanding fintech continuance: perspectives from self-efficacy and ECT-IS theories. Industrial Management and Data Systems, 120(9), 1659-1689. https://doi.org/10.1108/IMDS-022020-0069

Stocchi, L., Michaelidou, N., \& Micevski, M. (2019). Drivers and outcomes of branded mobile app usage intention. Journal of Product and Brand Management, 28(1), 28-49. https://doi.org/10.1108/JPBM-02-2017-1436

Trinh, H. N., Tran, H. H., \& Vuong, D. H. Q. (2020). Determinants of consumers' intention to use credit card: a perspective of multifaceted perceived risk. Asian Journal of Economics and Banking, 4(3), 105-120. https://doi.org/10.1108/ajeb-06-2020-0018

Wilson, N. (2019). The impact of perceived usefulness and perceived ease-of-use toward repurchase intention in the Indonesian e-commerce industry. Jurnal Manajemen Indonesia, 19(3), 241-249. https://doi.org/10.25124/jmi.v19i3.2412 